\title{
Pengaruh Bauran Promosi dan Destinasi Wisata terhadap Keputusan Berkunjung pada Wisata Taman Nasional Baluran
}

\section{Effects of Promotion and Tourism Destination Mix on Decisions Visiting Tourism in Baluran National Park}

\author{
Mokhamad Syaefudin Andrianto* \\ Departemen Manajemen, Fakultas Ekonomi dan Manajemen, IPB University, Dramaga, Bogor 16680 \\ e-mail: syaefudin1@apps.ipb.ac.id \\ Anis Daifatin Masruroh \\ Departemen Manajemen, Fakultas Ekonomi dan Manajemen, IPB University, Dramaga, Bogor 16680 \\ e-mail: anisraraw@yahoo.com
}

\begin{abstract}
Baluran National Park is one of the Indonesian interesting tour destinations to be visited by local and foreign tourists which is located in Situbondo, East Java. Promotion and condition of tourist destination components are needed to attract visitors. This research aimed to determine the effect of the promotion mix and tourist destination components on the decision to visit Baluran National Park. Primary data was taken by observation, interview with managers and also offline and online surveys. Purposive sampling with criteria minimal come in the last 2 years was used and taken of 100 respondents. The analytical method used descriptive analysis and Structural Equation Modeling (SEM) method with the Partial Least Square (PLS) approach. The results of the study showed that from variable promotion mix (advertising, promotion selling, direct marketing, public relation) and tourist destination components (Attraction, Accessibility, Ancillary, Amenities), only 3 variables; promotion selling, Attraction and Amenities were significant affect on visitors decision to come Baluran National Park.
\end{abstract}

Keywords: 4 A's, Baluran National Park, promotion mix, SEM-PLS, visiting decision.

\begin{abstract}
ABSTRAK
Taman Nasional Baluran merupakan salah satu tujuan wisata yang menarik untuk dikunjungi wisatawan nusantara maupun mancanegara yang terletak di Situbondo Jawa Timur. Strategi promosi dan kondisi tujuan wisata yang tepat dibutuhkan untuk meningkatkan kunjungan ke objek wisata terutama ikon wisata di daerah tersebut. Penelitian ini bertujuan untuk mengetahui pengaruh bauran promosi dan komponen destinasi wisata terhadap keputusan berkunjung pada wisata Taman Nasional Baluran. Data primer diambil melalui observasi, wawancara pengelola dan pengunjung. Teknik sampling menggunakan purposive sampling dengan contoh 100 responden yang di survey secara luring dan daring. Metode yang digunakan adalah analisis deskriptif dan metode Structural Equation Modeling (SEM) dengan pendekatan Partial Least Square (PLS). Hasil penelitian menunjukkan bahwa dari peubah bauran promosi (Iklan, Promposi Penjualan, Penjualan langsung dan Hubungan masyarakat) dan komponen destinasi wisata (Attraction, Accessibility, Ancillary dan Amenity), hanya peubah promosi penjualan, Attraction dan Amenity yang berpengaruh positif secara signifikan terhadap keputusan berkunjung.
\end{abstract}

Kata Kunci: 4A, bauran promosi, keputusan berkunjung, SEM-PLS, Taman Nasional Baluran. 


\section{PENDAHULUAN}

Sektor pariwisata merupakan salah satu sektor yang sangat berperan dalam pengembangan perekonomian negara melalui devisa yang dihasilkan. Undang-Undang Nomor 10 tahun 2009 tentang Kepariwisataan menyatakan bahwa penyelenggaraan kepariwisataan bertujuan meningkatkan pendapatan nasional untuk mempercepat pertumbuhan ekonomi demi meningkatkan kesejahteraan dan kemakmuran rakyat. Selain itu, Sektor pariwisata memiliki tujuan memperluas dan memeratakan kesempatan berusaha serta memberikan lapangan pekerjaan. Pariwisata juga mendorong pembangunan daerah, memperkenalkan objek dan daya tariknya serta mempromosikan kekayaan alam dan budaya Indonesia sehingga menarik wisatawan baik dari dalam maupun luar negeri.

Jumlah wisatawan yang berkunjung ke Indonesia, mengalami peningkatan dari tahun 2014 hingga tahun 2018. Pertumbuhan positif wisatawan terjadi baik dari wisatawan nusantara maupun mancanegara. Pertumbuhan wisatawan mancanegara walaupun masih positif, mengalami penurunan pada tahun 2017 ke tahun 2018. Sedangkan pertumbuhan wisatawan nusantara mengalami kenaikan yang tinggi. Pertumbuhan positif wisatawan nusantara dapat dimanfaatkan oleh pengelola objek wisata untuk menarik lebih banyak pengunjung pada tahuntahun mendatang. Perkembangan jumlah wisatawan mancanegara dan nusantara berdasarkan data dari Kementerian Pariwisata (Kemenpar) tahun 2014 - 2017 dapat dilihat pada Tabel 1.

Tabel 1. Perkembangan wisatawan nusantara dan mancanegara di Indonesia pada tahun 2014-2018

\begin{tabular}{lcccc}
\hline \multirow{2}{*}{ Tahun } & \multicolumn{2}{c}{ Wisatawan Nusantara } & \multicolumn{2}{c}{ Wisatawan Mancanegara } \\
\cline { 2 - 5 } & $\begin{array}{c}\text { Jumlah } \\
\text { (dalam juta) }\end{array}$ & Pertumbuhan (\%) & $\begin{array}{c}\text { Jumlah } \\
\text { (dalam juta) }\end{array}$ & Pertumbuhan (\%) \\
\hline 2014 & 25.124 & - & 8.788 & - \\
2015 & 25.642 & 2,41 & 10.364 & 17,92 \\
2016 & 26.434 & 2,99 & 12.023 & 16,01 \\
2017 & 27.000 & 2,09 & 14.039 & 16,76 \\
2018 & 30.340 & 11,0 & 15.610 & 11,18 \\
\hline
\end{tabular}

Sumber: Kementerian Pariwisata (2019)

Destinasi wisata di Indonesia memiliki beberapa macam yaitu, wisata alam dan buatan. Wisata alam dapat berupa taman nasional, cagar alam dan suaka marga satwa. Sedangkan wisata buatan dapat terdiri dari agrowisata, kebun binatang, dan museum ataupun laboratorium pengetahuan. Ketertarikan wisatawan lebih condong pada wisata alam karena Indonesia memiliki keberagaman destinasi wisata alam mulai dari Sabang hingga Merauke.

Jawa Timur memiliki potensi pariwisata meliputi 760 daerah tujuan wisata dengan rincian 264 daerah wisata alam, 306 daerah wisata budaya dan 190 tujuan wisata minat khusus seperti Taman Nasional Baluran, Taman Nasional Bromo Tengger Semeru, Taman Nasional Meru Betiri dan Taman Nasional Alas Purwo. Taman Nasional Baluran yang selanjutnya disebut TNB adalah salah satu destinasi wisata strategis di Jawa Timur yang terletak di Kabupaten Situbondo. Strategis karena Situbondo sering dijadikan transit wisatawan yang akan pergi ke Bali dari Pulau Jawa melalui darat. Selain itu, Taman Nasional menurut Pasal 1 Undang-Undang Nomor 5 Tahun 1990 tentang Konservasi Sumber Daya Alam Hayati dan Ekosistemnya, pada ayat (14), diartikan sebagai kawasan pelestarian alam yang mempunyai ekosistem asli, dikelola dengan sistem zonasi, yang dimanfaatkan untuk tujuan penelitian, pendidikan, menunjang budidaya pariwisata dan rekreasi.

Keunikan TNB memiliki ekosistem hutan kering yang mirip di Afrika dan memiliki Evergreen Forest dimana hutan terlihat hijau sepanjang musim karena adanya awan tebal berukuran besar yang menaungi kawasan tersebut, tidak berpindah ke tempat lain meskipun angin tertiup kencang. Pengunjung TNB didominasi oleh wisatawan nusantara. Peningkatan kunjungan TNB terjadi pada tahun 2013 sampai tahun 2015, tetapi pada tahun 2015 sampai 
Tabel 2. Perkembangan kunjungan wisatawan nusantara dan mancanegara wisata Taman Nasional Baluran

\begin{tabular}{lccc}
\hline \multirow{2}{*}{ Tahun } & \multicolumn{2}{c}{ Kunjungan Ke Objek Wisata } & \\
\cline { 2 - 4 } & $\begin{array}{c}\text { Wisatawan Nusantara } \\
\text { (Orang) }\end{array}$ & $\begin{array}{c}\text { Wisatawan Mancanegara } \\
\text { (Orang) }\end{array}$ & Total \\
\hline 2013 & 38.858 & 1.016 & 39.874 \\
2014 & 59.089 & 1.212 & 60.301 \\
2015 & 91.742 & 1.312 & 93.054 \\
2016 & 91.623 & 1.193 & 92.816 \\
2017 & 84.844 & 1.210 & 86.054 \\
\hline
\end{tabular}

Sumber: Dinas Pariwisata dan Kebudayaan Kota Situbondo (2018)

Penurunan kunjungan ini perlu dikaji dari berbagai aspek. Menurut aspek pemasaran, konsumen memiliki perilaku pembelian yang cukup rumit dalam menentukan keputusan, begitu pula dengan penentuan kunjungan ke tujuan wisata. Menurut Armstrong et al. (2017), terdapat tahapan dan rangsangan yang memengaruhi keputusan pembelian. Tahapan tersebut terdiri dari lima urutan yaitu pengenalan kebutuhan, pencarian informasi, evaluasi alternatif, keputusan pembelian, dan perilaku pasca pembelian. Sedangkan rangsangan selain dipengaruhi oleh aspek makro juga dipengaruhi oleh aspek mikro antara lain dipengaruhi oleh promosi, citra produk, harga dan saluran distribusi.

Menurut Hania et al. (2016), keputusan berkunjung ke objek wisata dipengaruhi oleh bauran promosi dan citra destinasi. Pengunjung dapat mengetahui objek wisata yang ada melalui promosi yang dilakukan oleh pihak pengelola dan pemerintah dalam hal ini adalah dinas pariwisata daerah tersebut. Bentuk-bentuk promosi yang dapat dilakukan oleh pengelola wisata antara lain periklanan, promosi penjualan, hubungan masyarakat, penjualan pribadi, dan pemasaran langsung (Armstrong et al., 2017). Marketing public relation atau hubungan masyarakat sangat penting dalam meningkatkan citra destinasi pariwisata (Saputra and Sarma 2020).

Komponen produk destinasi wisata dipengaruhi oleh 4 (empat) aspek yaitu attraction, accessibility, amenities dan ancillary (Arisandi et al., 2014; Astuti \& Noor, 2016; Ismail \& Rohman, 2019). Attraction bisa berupa keindahan alam, budaya, peninggalan bersejarah ataupun atraksi buatan yang dapat menarik pengunjung berwisata. Sedangkan Accessibility bisa berupa jalan, rambu-rambu ataupun kemudahan transportasi menuju tempat wisata (Wanda, 2018). Amenity terkait dengan sarana pendukung seperti ketersediaan makanan, minuman dan penginapan. Sedangkan ancillary terkait dengan informasi pendukung seperti manajemen, dan asosiasi wisata (Andrianto \& Sugiama, 2016). Berdasarkan hal tersebut, Penelitian ini bertujuan mengidentifikasi karakteristik pengunjung, merumuskan bauran promosi serta komponen destinasi wisata yang memengaruhi kunjungan ke TNB.

\section{METODE PENELITIAN}

Perkembangan sektor pariwisata di Indonesia sejak tahun 2014-2017 mengalami peningkatan. Sementara kunjungan wisata ke TNB pada tahun 2017 mengalami penurunan. Berdasarkan hal tersebut, perlu ditentukan karakteristik pengunjung, bauran promosi dan komponen destinasi wisata yang memengaruhi kunjungan tersebut. Keputusan berkunjung menggunakan tahapan pengenalan masalah, pencarian informasi, evaluasi alternatif, keputusan pembelian dan perilaku pasca pembelian (Armstrong et al., 2017). Mengingat objek studi dari penelitian ini merupakan objek pariwisata sehingga penjualan pribadi sulit dilakukan bahkan seringkali tidak dilakukan oleh pengelola wisata maka penjualan pribadi tidak digunakan sebagai salah satu peubah dalam penelitian ini. Destinasi wisata menggunakan pendekatan konsep 4A untuk menguji pengaruhnya kepada pengambilan keputusan kunjungan ke TNB. Kerangka pemikiran penelitian dijelaskan dalam Gambar 1. 


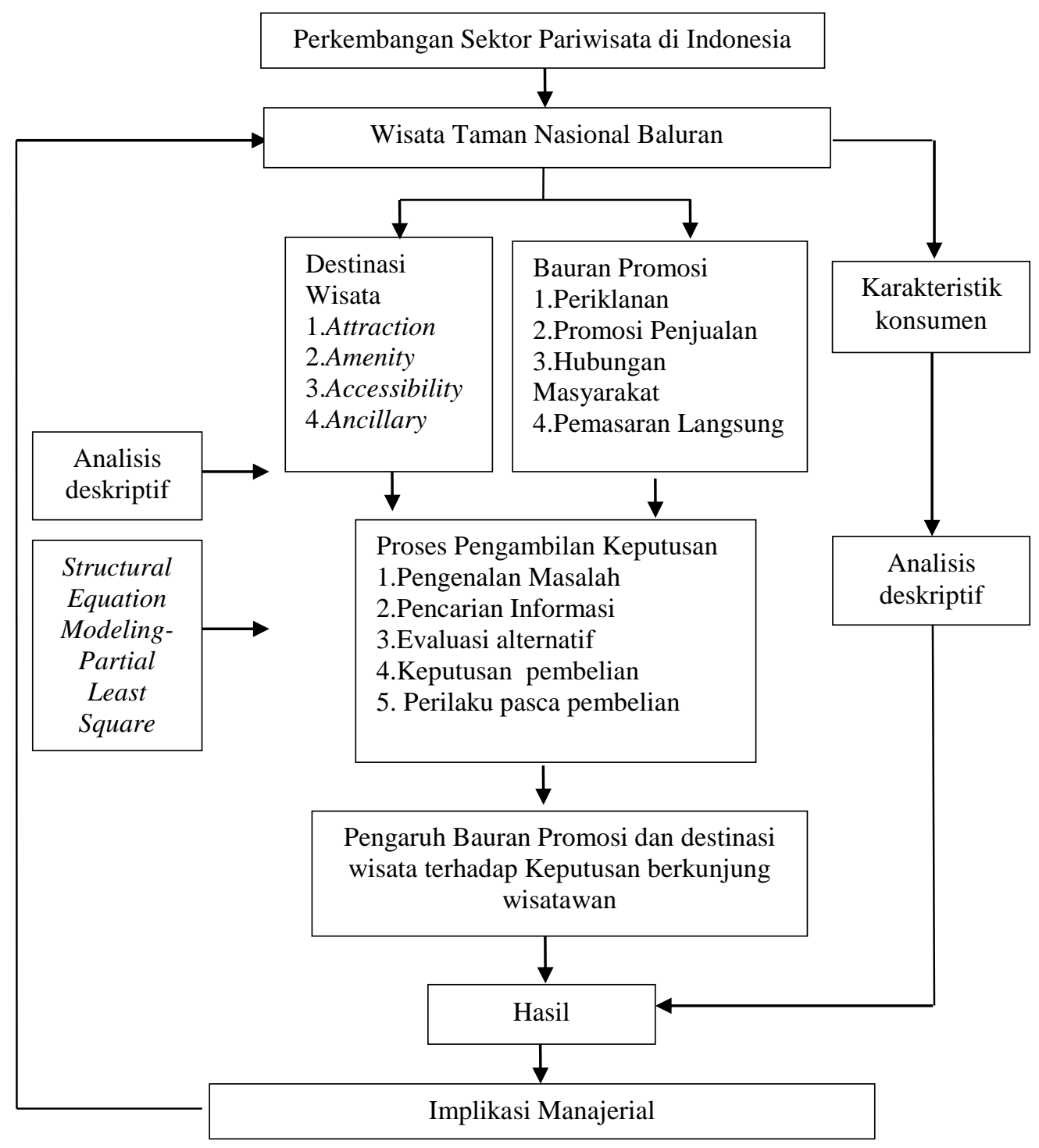

Gambar 1. Kerangka pemikiran

Peubah bebas (independen) merupakan peubah yang menjadi sebab terjadinya perubahan pada peubah terikat (dependen). Dalam penelitian ini, bauran promosi sebagai peubah bebas terdiri dari periklanan (X1), promosi penjualan (X2), hubungan masyarakat (X3) dan pemasaran langsung (X4) dan terdapat juga komponen destinasi pariwisata yang mencangkup 4A juga sebagai peubah bebas yang terdiri dari Attraction (A1), Amenity (A2), Accessibility (A3), Ancillary(A4). Model keputusan berkunjung ke TNB dijelaskan pada Gambar 2 dan indikator yang digunakan dijelaskan pada Tabel 3. 


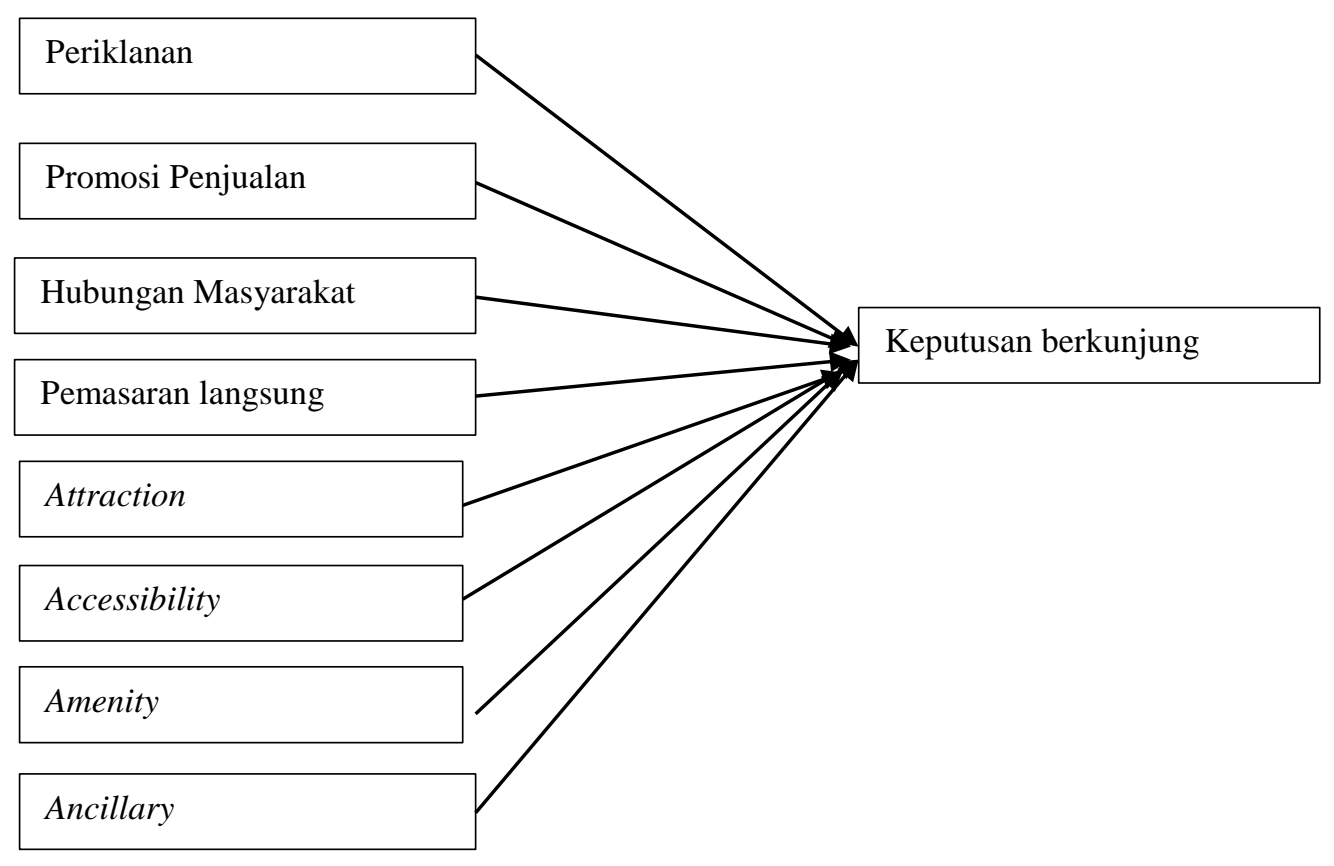

Gambar 2. Model keputusan berkunjung ke Taman Nasional Baluran

\section{Hipotesis Penelitian}

Hipotesis yang digunakan dalam penelitian ini, yaitu:

$\mathrm{H}_{01}$ : Tidak terdapat pengaruh signifikan Periklanan terhadap Keputusan Berkunjung.

$\mathrm{H}_{11}$ : Terdapat pengaruh signifikan Periklanan terhadap Keputusan Berkunjung.

$\mathrm{H}_{02}$ : Tidak terdapat pengaruh signifikan Promosi Penjualan terhadap Keputusan Berkunjung.

$\mathrm{H}_{12}$ : Terdapat pengaruh signifikan Promosi Penjualan terhadap Keputusan Berkunjung.

$\mathrm{H}_{03}$ : Tidak terdapat pengaruh signifikan Hubungan Masyarakat terhadap Keputusan

\section{Berkunjung.}

$\mathrm{H}_{13}$ : Terdapat pengaruh signifikan Hubungan Masyarakat terhadap Keputusan Berkunjung.

$\mathrm{H}_{04}$ : Tidak terdapat pengaruh signifikan Penjualan Langsung terhadap Keputusan Berkunjung.

$\mathrm{H}_{14}$ : Terdapat pengaruh signifikan Penjualan Langsung terhadap Keputusan Berkunjung.

$\mathrm{H}_{05}$ : Tidak terdapat pengaruh signifikan Attraction terhadap Keputusan Berkunjung.

$\mathrm{H}_{15}$ : Terdapat pengaruh signifikan Attraction terhadap Keputusan Berkunjung.

$\mathrm{H}_{06}$ : Tidak terdapat pengaruh signifikan Amenity terhadap KeputusanBerkunjung.

$\mathrm{H}_{16}$ : Terdapat pengaruh signifikan Amenity terhadap Keputusan Berkunjung.

$\mathrm{H}_{07}$ : Tidak terdapat pengaruh signifikan Accessibility terhadap Keputusan Berkunjung.

$\mathrm{H}_{17}$ : Terdapat pengaruh signifikan Accessibility terhadap Keputusan Berkunjung.

$\mathrm{H}_{08}$ : Tidak terdapat pengaruh signifikan Ancillary terhadap Keputusan Berkunjung.

$\mathrm{H}_{18}$ : Terdapat pengaruh signifikan Ancillary terhadap Keputusan Berkunjung. 
Tabel 3. Peubah, dimensi dan indikator

\begin{tabular}{|c|c|c|c|}
\hline Peubah & Dimensi & Indikator reflektif & Notasi \\
\hline \multirow{15}{*}{$\begin{array}{l}\text { Bauran } \\
\text { Promosi }\end{array}$} & \multirow[t]{4}{*}{ Periklanan (PR) } & Iklan dalam berbentuk brosur/ flyer/ spanduk & PR1 \\
\hline & & $\begin{array}{l}\text { Iklan dalam media sosial (facebook, instagram, } \\
\text { twitter, pinterest, dll) }\end{array}$ & PR2 \\
\hline & & Iklan dari media elektronik (televisi atau radio) & PR3 \\
\hline & & $\begin{array}{l}\text { Iklan dalam website yang merekomendasikan tempat } \\
\text { wisata }\end{array}$ & PR4 \\
\hline & \multirow[t]{4}{*}{$\begin{array}{l}\text { Promosi } \\
\text { Penjualan (PP) }\end{array}$} & $\begin{array}{l}\text { Mendapat paket promo harga tiket masuk untuk } \\
\text { pengunjung rombongan }\end{array}$ & PP1 \\
\hline & & Mendapat teh dan kue & PP2 \\
\hline & & Fasilitas yang nyaman & PP3 \\
\hline & & $\begin{array}{l}\text { Promosi melalui foto-foto yang beredar membuat } \\
\text { tertarik untuk berkunjung }\end{array}$ & PP4 \\
\hline & \multirow{4}{*}{$\begin{array}{l}\text { Hubungan } \\
\text { Masyarakat } \\
(\mathrm{HM})\end{array}$} & Dinas pariwisata dan pengelola membangun citra & HM1 \\
\hline & & baik untuk wisata Taman Nasional Baluran & HIMI \\
\hline & & $\begin{array}{l}\text { Masyarkat setempat dapat berjualan disekitar tempat } \\
\text { wisata }\end{array}$ & HM2 \\
\hline & & $\begin{array}{l}\text { Masyarakat setempat membantu mengelola tempat } \\
\text { wisata }\end{array}$ & HM3 \\
\hline & \multirow[t]{3}{*}{$\begin{array}{l}\text { Pemasaran } \\
\text { Langsung(PL) }\end{array}$} & $\begin{array}{l}\text { Mengikuti sosialisasi dari pemerintah tentang wisata } \\
\text { daerah }\end{array}$ & PL1 \\
\hline & & Mendapat telepon/sms/email & PL2 \\
\hline & & Mendapat informasi dari website dinas pariwisata & PL3 \\
\hline \multirow{20}{*}{$\begin{array}{l}\text { Destinasi } \\
\text { Wisata }\end{array}$} & \multirow[t]{4}{*}{ Attraction (AT) } & Kawasan wisata terawat dengan baik & AT1 \\
\hline & & Savana dan pantai yang indah & AT2 \\
\hline & & Hewan yang tidak membahayakan pengunjung & AT3 \\
\hline & & Lokasi/ spot foto yang menarik & AT4 \\
\hline & \multirow[t]{7}{*}{ Amenity (AM) } & Lahan parkir luas & AM1 \\
\hline & & Loket yang terawat dengan baik dan bersih & AM2 \\
\hline & & Harga tiket terjangkau & AM3 \\
\hline & & Nomor telepon untuk keluhan/ pengaduan & AM4 \\
\hline & & Terdapat brosur & AM5 \\
\hline & & $\begin{array}{l}\text { Ada toilet didalam ataupun diluar dengan kondisi } \\
\text { bersih }\end{array}$ & AM6 \\
\hline & & Jaminan keamanan & AM7 \\
\hline & \multirow{5}{*}{$\begin{array}{l}\text { Accessibility } \\
\text { (A3) }\end{array}$} & Jarak dari pusat keramaian tidak jauh & $\mathrm{AC} 1$ \\
\hline & & $\begin{array}{l}\text { Adanya sarana transportasi yang memudahkan } \\
\text { wisatawan }\end{array}$ & $\mathrm{AC} 2$ \\
\hline & & Kondisi jalan terawatt & $\mathrm{AC} 3$ \\
\hline & & Papan petunjuk arah yang memudahkan pengunjung & $\mathrm{AC} 4$ \\
\hline & & Signal komunikasi yang baik & AC5 \\
\hline & \multirow[t]{4}{*}{ Ancillary (A4) } & Ada jasa pelayanan servis kendaraan & AN1 \\
\hline & & Penginapan di sekitar objek wisata & AN2 \\
\hline & & Kelas penginapan yang beragam & AN3 \\
\hline & & $\begin{array}{l}\text { Harga penginapan yang ditawarkan sesuai dengan } \\
\text { pengeluaran pengunjung }\end{array}$ & AN4 \\
\hline \multirow{4}{*}{$\begin{array}{l}\text { Keputusan } \\
\text { Berkunjung } \\
(\mathrm{KB})\end{array}$} & & Banyak direkomendasikan orang lain & KB1 \\
\hline & & Mengetahui dari keluarga/teman/kerabat & KB2 \\
\hline & & Ingin berkunjung kembali & KB3 \\
\hline & & Berkunjung karena lokasi mudah dijangkau & KB4 \\
\hline
\end{tabular}




\section{HASIL DAN PEMBAHASAN}

\section{Karakteristik Responden}

Analisis deskripsi dilakukan untuk mengidentifikasi karakteristik responden secara umum. Responden dalam penelitian ini adalah wisatawan yang sudah pernah berkunjung ke TNB dalam kurun waktu dua tahun terakhir. Responden yang dilibatkan sebanyak 100 orang. Mayoritas pengunjung TNB berjenis kelamin perempuan berusia 18-25 tahun berdomisili di Jawa Timur. Selain hal tersebut, Mayoritas pengunjung adalah pelajar/mahasiswa (43 persen) dengan pemasukan kurang dari Rp. 1.500.000,00. Walaupun pelajar memiliki pemasukan tidak banyak, tetapi pelajar muda memiliki jiwa petualang yang aktif dalam mencari tempat-tempat baru serta memiliki kebiasaan mengunggah pengalaman berwisata secara personal maupun kelompok ke media sosial, sehingga secara tidak langsung menjadi informasi dan promosi tentang wisata TNB.

Mayoritas pengunjung datang dengan tujuan mengisi liburan dan sumber utama informasi mengenai wisata dari teman/keluarga (49 persen). TNB merupakan prioritas utama wisata, walaupun adanya hewan-hewan liar di TNB menyebabkan wisatawan merasa terancam. Loyalitas pengunjung cukup tinggi hal ini dibuktikan dengan kesediaan melakukan kunjungan ulang hingga 98 persen (Tabel 4).

Tabel 4. Karakteritik pengunjung wisata Taman Nasional Baluran

\begin{tabular}{|c|c|c|}
\hline Kategori & Keterangan & Persentase $(\%)$ \\
\hline \multirow[t]{2}{*}{ Jenis Kelamin } & Perempuan & 59 \\
\hline & Laki-laki & 41 \\
\hline \multirow[t]{5}{*}{ Usia (tahun) } & $<18$ & 8 \\
\hline & $18-25$ & 57 \\
\hline & $26-35$ & 20 \\
\hline & $36-45$ & 10 \\
\hline & $>45$ & 5 \\
\hline \multirow[t]{5}{*}{ Pekerjaan/ status } & Pelajar / Mahasiswa & 43 \\
\hline & Pegawai Swasta & 17 \\
\hline & Pegawai Negeri & 1 \\
\hline & Wiraswasta & 31 \\
\hline & Lainnya & 7 \\
\hline \multirow[t]{5}{*}{ Pendapatan / bulan (Rupiah) } & $<1500000$ & 59 \\
\hline & $1500000-3000000$ & 25 \\
\hline & $3000001-4500000$ & 6 \\
\hline & $4500001-7500000$ & 8 \\
\hline & $>7500000$ & 2 \\
\hline \multirow[t]{2}{*}{ Domisili } & Jawa Timur & 93 \\
\hline & Luar Jawa Timur & 7 \\
\hline \multirow[t]{5}{*}{ Tujuan Berkunjung } & Liburan & 47 \\
\hline & Mengisi Waktu Kosong & 1 \\
\hline & Menikmati Suasana Alam & 40 \\
\hline & Berkumpul dengan Keluarga & 3 \\
\hline & Lainnya & 9 \\
\hline \multirow[t]{6}{*}{ Sumber Informasi } & Keluarga/teman & 49 \\
\hline & Media cetak (brosur, koran, dll) & 1 \\
\hline & Media elektronik (televisi, radio) & 1 \\
\hline & $\begin{array}{l}\text { Media sosial (Instagram, twitter, } \\
\text { facebook) }\end{array}$ & 30 \\
\hline & Internet (website, app travelling) & 11 \\
\hline & Lainnya & 8 \\
\hline \multirow[t]{2}{*}{ Pilihan Prioritas } & Ya & 83 \\
\hline & Tidak & 17 \\
\hline \multirow[t]{2}{*}{ Keamanan Terancam } & Ya & 86 \\
\hline & Tidak & 14 \\
\hline Alasan Berkunjung ke TNB & Lokasi yang mudah dijangkau & 19 \\
\hline
\end{tabular}

Jurnal Manajemen dan Organisas JMO), Vol. 11 No. 2 Agustus 2020
Hal. $71-82$ 


\begin{tabular}{lll}
\hline Kategori & Keterangan & Persentase (\%) \\
\hline & Suasana yang nyaman & $\mathbf{4 7}$ \\
& Harga tiket masuk murah & 5 \\
& Fasilitas untuk bersantai & 12 \\
& Lainnya & 16 \\
\multirow{2}{*}{ Melakukan kunjungan ulang } & Ya & $\mathbf{9 8}$ \\
& Tidak & 2 \\
\hline
\end{tabular}

\section{Analisis Bauran Promosi dan Destinasi Wisata}

Analisis Evaluasi Model Pengukuran (Outer Model)

Analisis evaluasi model pengukuran atau outer model berfungsi untuk melihat apakah setiap indikator berhubungan dengan peubah laten lainnya. Terdapat 3 aspek yang digunakan pada outer model yaitu convergent validity, discriminant validity, dan composite reliability. Convergent validity menurut Ghozali (2014) data dapat dikatakan valid apabila nilai dari outer loading factor di atas 0,7, sedangkan discriminant validity dapat dikatakan baik apabila nilai Average variance Extracted (AVE) di atas 0,5. Composite Reliability dinyatakan reliabel jika memiliki nilai di atas 0,7 .

Pada pengolahan awal outer model, 38 indikator yang diusulkan diolah dan dievaluasi loading factor nya. Indikator yang kurang dari 0,7 di hilangkan sehingga hasil akhirnya tersisa 22 indikator (Gambar 3).

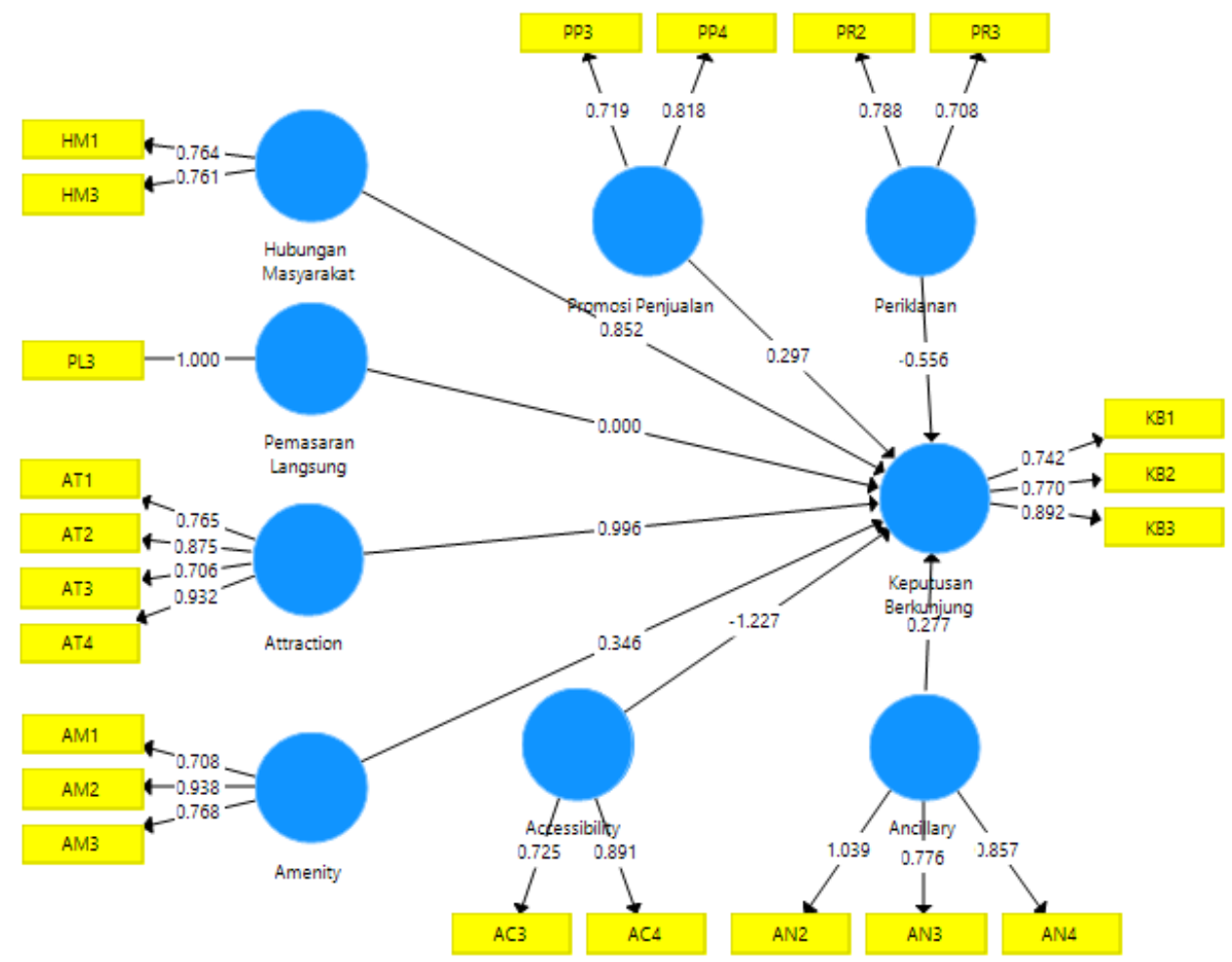

Gambar 3. Hasil Outer Model Akhir

Pengujian kedua yaitu discriminant validity dengan melihat Average Variance Extracted (AVE) dengan syarat nilai AVE harus di atas 0,5. Pada pengujian ini, seluruh peubah laten telah memiliki nilai AVE di atas 0,5 sehingga telah memenuhi kriteria dan dapat dinyatakan valid. Selanjutnya dilakukan pengukuran reliabilitas dengan melihat nilai composite reliability, dengan kriteria nilai output lebih dari 0,7 . Berdasarkan evaluasi outer model semua konstruk dapat dikatakan reliabel dan telah memenuhi uji validitas dan reliabilitas. Nilai AVE dan composite reliability dapat dilihat pada Tabel 5 . 
Tabel 5. Nilai Average Variance Extracted (AVE)

\begin{tabular}{lcc}
\hline Peubah laten & Nilai AVE & Composite reliability \\
\hline Periklanan & 0,562 & 0,719 \\
Promosi Penjualan & 0,593 & 0,744 \\
Hubungan Masyarakat & 0,581 & 0,735 \\
Pemasaran Langsung & 1,000 & 1,000 \\
Attraction & 0,679 & 0,893 \\
Amenity & 0,657 & 0,850 \\
Accessibility & 0,660 & 0,794 \\
Ancillary & 0,809 & 0,924 \\
Keputusan Berkunjung & 0,646 & 0,845 \\
\hline
\end{tabular}

Analisis Evaluasi Model Struktural (Inner Model)

Evaluasi model struktural atau inner model digunakan untuk menguji pengaruh antara suatu peubah laten dengan peubah laten lainnya baik eksogen maupun endogen. Pengaruh dari peubah independen secara keseluruhan dapat dilihat pada nilai R-square dengan menggunakan bootstraping. Hasil analisis menunjukkan bahwa nilai $R$-Square pada peubah keputusan kunjungan memiliki 0,728 yang berarti semua peubah independen (periklanan, promosi penjualan, hubungan masyarakat, pemasaran langsung, attraction, amenity, accessibilitydan ancillary) secara simultan mampu menjelaskan peubah dependen (keputusan kunjungan) sebesar 72, 8 persen, sedangkan sisanya dijelaskan oleh peubah lain yang tidak dirumuskan pada model ini. Hasil bootstraping dapat dilihat pada Gambar 4.

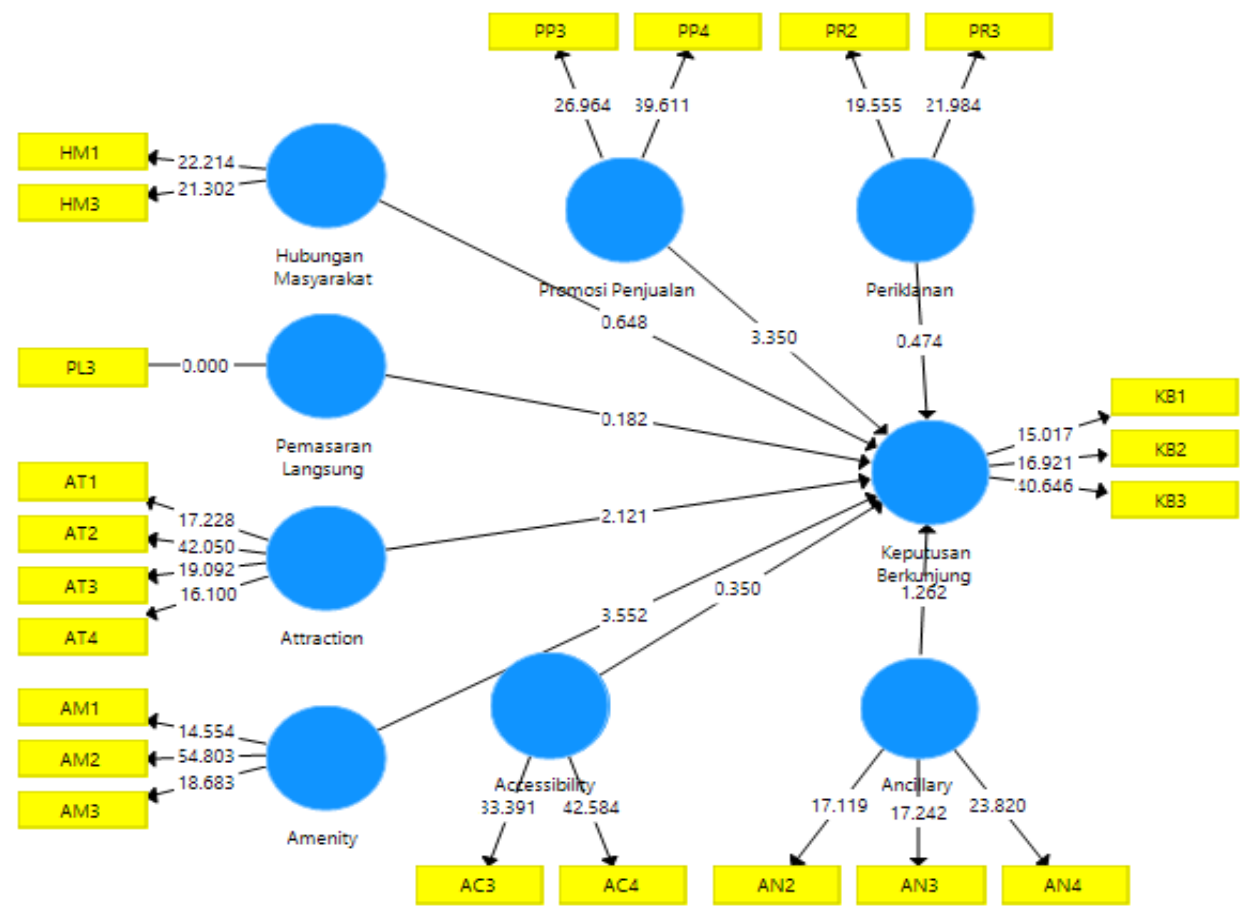

Gambar 4. Hasil Bootstraping

\section{Pengujian Hipotesis (Resampling Bootsraping)}

Tahap selanjutnya adalah pengujian hipotesis dari analisis antar peubah dengan metode resampling bootstraping. Evaluasi dengan melihat hasil path coefficients. Kriteria pengujian ini dapat dilihat dari nilai T statistik $>1,96$ atau $p$-value $<0,05$ dengan tingkat signifikansi 5 persen. Hasil pengujian hipotesis, terdapat 3 peubah yang berpengaruh yaitu Promosi penjualan, Attraction dan Amenity (Tabel 6). 
Tabel 6. Nilai path coefficient

\begin{tabular}{|c|c|c|c|c|}
\hline Peubah & $\begin{array}{c}\text { Original } \\
\text { sample }\end{array}$ & T-statistik & $\begin{array}{c}\mathrm{P} \\
\text { values }\end{array}$ & Hipotesis \\
\hline Periklanan-> Keputusan Berkunjung & 0,038 & 0,474 & 0,636 & Tidak Berpengaruh \\
\hline $\begin{array}{l}\text { Promosi Penjualan-> Keputusan } \\
\text { Berkunjung }\end{array}$ & 0,403 & 3,350 & $\mathbf{0 , 0 0 1}$ & Berpengaruh \\
\hline $\begin{array}{l}\text { Hubungan Masyarakat -> Keputusan } \\
\text { Berkunjung }\end{array}$ & 0,075 & 0,648 & 0,517 & Tidak berpengaruh \\
\hline $\begin{array}{l}\text { Pemasaran Langsung -> Keputusan } \\
\text { Berkunjung }\end{array}$ & 0,014 & 0,182 & 0,855 & Tidak berpengaruh \\
\hline Attraction -> Keputusan Berkunjung & 0,254 & 2,121 & $\mathbf{0 , 0 3 4}$ & Berpengaruh \\
\hline Amenity -> Keputusan Berkunjung & $\mathbf{0 , 3 0 2}$ & 3,552 & 0,000 & Berpengaruh \\
\hline Accessibility-> Keputusan Berkunjung & $-0,039$ & 0,350 & 0,727 & Tidak berpengaruh \\
\hline Ancillary -> Keputusan Berkunjung & $-0,103$ & $-0,097$ & 1,262 & Tidak berpengaruh \\
\hline
\end{tabular}

\section{Pengaruh Promosi Penjualan terhadap keputusan berkunjung}

Indikator fasilitas yang nyaman (PP3) dan foto-foto menarik yang beredar (PP4) memengaruhi orang untuk berkunjung ke TNB. Fasilitas objek wisata TNB sesuai dengan tren yang sedang diminati konsumen, tidak hanya itu kebersihan, kelancaran dan jaminan keamanan dari fasilitas juga menjadi nilai tambah untuk menarik konsumen untuk berkunjung. Menurut Tjiptono (2011) fasilitas merupakan sumber daya fisik yang harus ada sebelum jasa ditawarkan kepada pengunjung. Fasilitas yang disediakan pada Objek Wisata TNB sudah cukup memadai. Fasilitas dan keindahan alam TNB di foto dan dipromosikan baik oleh pengunjung maupun pengelola menyebabkan wisatawan lain ingin berkunjung ke TNB.

\section{Pengaruh Attraction terhadap keputusan berkunjung}

Peubah Attraction yang memiliki indikator tertinggi adalah adanya savana dan pantai yang indah (AT2). Adanya savana Bekol yang luas dan pantai Bama yang indah dengan hamparan pasir putih yang berpadu dengan hutan mangrove juga dapat menarik perhatian lebih dari pengunjung wisata. Attraction ini juga didukung oleh indikator adanya kawasan wisata yang terawat dengan baik (AT1) dan lokasi spot foto yang menarik (AT4).

Foto yang menarik dapat disebar melalui media sosial. Media sosial Instagram merupakan media yang sangat memengaruhi wisatawan muda untuk berkunjung ke TNB. Hal ini disebabkan oleh beberapa fitur yang menarik dalam media sosial ini berupa foto, tulisan dan tag (memberi tanda) lokasi. Keputusan berkunjung karena adanya attraction diperkuat oleh jawaban deskriptif survey yaitu sumber informasi TNB terutama dari rekomendasi teman ataupun orang lain dan media sosial.

\section{Pengaruh Amenity terhadap keputusan berkunjung}

Kondisi loket (AM2), harga (AM3) dan lahan parkir yang luas (AM1) juga memengaruhi kenyamanan berkunjung. Penataan loket yang baik memudahkan antrian. Sedangkan paket harga yang diberikan TNB pada tahun 2019 relatif terjangkau yaitu untuk tiket di hari kerja Rp. 15.000,00 untuk domestik dan Rp. 150.000,00 untuk mancanegara sedangkan untuk rombongan pelajar atau mahasiswa yaitu Rp. 8.000,00. Untuk kendaraan yang dibawa oleh pengunjung juga dikenai tarif biaya yaitu untuk roda dua Rp. 5.000,00, untuk roda empat yaitu Rp. 10.000,00 dan untuk minibus atau truk yaitu Rp. 50.000,00.

Berdasarkan hasil penelitian dapat dilihat bahwa bauran promosi khususnya promosi penjualan dan komponen destinasi wisata khususnya Attraction dan Amenity pada TNB memengaruhi keputusan berkunjung. Sedangkan komponen yang lain belum dianggap mampu mempengaruhi keputusan berkunjung. Implikasi manajerial pada penelitian ini dapat diterapkan pada bauran promosidengan fungsi manajemen yaitu planning, organizing, actuating, dan controlling, hal ini dapat membantu pihak pengelola, pemerintah, dan usaha sejenis terkait bidang pariwisata. Implikasi manajerial pada bauran promosi dengan fungsi manajemen akan disajikan pada Tabel 7. 
Tabel 7. Implikasi Manajerial Bauran Promosi dan komponen destinasi wisata

\begin{tabular}{|c|c|c|c|c|}
\hline & Planning & Organizing & Actuating & Controlling \\
\hline $\begin{array}{l}\text { Promosi } \\
\text { Penjualan }\end{array}$ & $\begin{array}{l}\text { Meningkatkan } \\
\text { fasilitas untuk } \\
\text { pengunjung. } \\
\text { Memberikan } \\
\text { kemudahan } \\
\text { pengunjugn } \\
\text { berfoto. }\end{array}$ & $\begin{array}{l}\text { Menyelenggaraka } \\
\mathrm{n} \text { kerjasama } \\
\text { dengan asosiasi } \\
\text { dan pengunjung } \\
\text { untuk } \\
\text { mempromosikan } \\
\text { keindahan TNB } \\
\text { termasuk kontes } \\
\text { foto TNB }\end{array}$ & $\begin{array}{l}\text { Membuat event yang berlokasi } \\
\text { di TNB dan bekerja sama } \\
\text { dengan lembaga-lembaga } \\
\text { pariwisata dengan memberikan } \\
\text { paket promo yang menarik. } \\
\text { Seperti mengadakan promo } \\
\text { pada hari hari tertentu misalnya } \\
\text { promo pada hari konservasi } \\
\text { alam nasional setiap tanggal } 10 \\
\text { Agustus, promo hari menanam } \\
\text { pohon Indonesia setiap tanggal } \\
28 \text { November. }\end{array}$ & $\begin{array}{l}\text { Melakukan } \\
\text { evaluasi } \\
\text { terhadap } \\
\text { kepuasan } \\
\text { berkunjung }\end{array}$ \\
\hline Attraction & $\begin{array}{l}\text { Mempertahank } \\
\text { an keindahan } \\
\text { dan kebersihan } \\
\text { savana dan } \\
\text { pantai }\end{array}$ & $\begin{array}{l}\text { Menyediakan } \\
\text { tanda- tanda } \\
\text { tempat sampah } \\
\text { ataupun menjaga } \\
\text { kebersihan dan } \\
\text { kenyamanan } \\
\text { bersama }\end{array}$ & $\begin{array}{l}\text { Mengingatkan pengunjung } \\
\text { untuk bersama-sama menjaga } \\
\text { keindahan dan kebersihan serta } \\
\text { Memperbanyak spot-spot } \\
\text { menarik }\end{array}$ & $\begin{array}{l}\text { Melakukan } \\
\text { survey berkala } \\
\text { untuk } \\
\text { kebersihan. } \\
\text { Pelayanan dan } \\
\text { penambahan } \\
\text { spot }\end{array}$ \\
\hline Amenity & $\begin{array}{l}\text { Mempertahank } \\
\text { an Informasi } \\
\text { harga tiket dan } \\
\text { kemudahan } \\
\text { parkir di pintu } \\
\text { gerbang }\end{array}$ & $\begin{array}{l}\text { Menjaga } \\
\text { kebersihan dan } \\
\text { ketersediaan toilet }\end{array}$ & Menjaga kenyaman pengunjung & $\begin{array}{l}\text { Melakukan } \\
\text { survey terkait } \\
\text { pelayanan dan } \\
\text { pendukung } \\
\text { yang } \\
\text { diperlukan }\end{array}$ \\
\hline
\end{tabular}

\section{KESIMPULAN}

Berdasarkan penelitian yang telah dilakukan diperoleh simpulan sebagai berikut:

1. Karakteristik pengunjung wisata TNB mayoritas berjenis kelamin perempuan dengan usia 18-25 tahun dan berdomisili di Jawa Timur. Mayoritas pengunjung adalah pelajar/mahasiswa dengan tingkat pemasukan kurang dari Rp. 1.500.000,00.

2. Proses pengambilan keputusan yang dilakukan wisatawan dalam melakukan kegiatan berkunjung dimulai dari pengenalan kebutuhan dimana mayoritas responden memilih alasan berkunjung untuk liburan. Pada tahap pencarian informasi responden lebih banyak mendapatkan informasi dari teman atau keluarga dan media sosial. Pada tahap evaluasi alternatif responden memutuskan pilihan untuk menjadikan destinasi wisata TNB sebagai pilihan prioritas. Pada tahap keputusan pembelian, responden mengunjungi wisata dengan alasan suasana yang nyaman. Pada tahap perilaku pasca pembelian, konsumen merasa senang, hampir seluruh wisatawan bersedia untuk mengunjungi kembali TNB.

3. Promosi penjualan, Attraction dan Amenity memengaruhi keputusan wisatawan berkunjung ke TNB.

\section{DAFTAR PUSTAKA}

Armstrong, G., Kotler, P., \& Opresnik, M. O. (2017). Marketing: An Introduction. Thirteenth Global Edition. London. Pearson Education.

Andrianto, T., \& Sugiama, G. (2016). The Analysis of Potential 4A's Tourism Component in the Selasari Rural Tourism,Pangandaran, West Java. In: Proceedings of the Asia Tourism Forum 2016 - the 12th Biennial Conference of Hospitality and Tourism Industry in Asia. p. 138-144.

Astuti, M. T., \& Noor, A. A. (2016). Daya Tarik Morotai Sebagai Destinasi Wisata Sejarah Dan Bahari. J Kepariwisataan Indonesia, 11(1), 25-46.

[DISPARBUD] Dinas Pariwisata dan Kebudayaan Kota Situbondo. (2018). Perkembangan wisatawan nusantara dan mancanegara wisata Taman Nasional Baluran. Diakses pada [5Mei 2019]. Tersedia pada https://situbondokab.bps.go.id

Jurnal Manajemen dan Organisas (JMO), Vol. 11 No. 2 Agustus 2020 Hal. 71-82 
Ghozali, I., \& Latan, H. (2014). Partial Least Squares: Konsep, Teknik dan Aplikasi Menggunakan Program SmartPLS 3.0. Yogyakarta: Badan Penerbit UNDIP. Ed ke-4

Hania, A., Sunarti, S., \& Pangestuti, E. (2016). Pengaruh Bauran Promosi Terhadap Keputusan Berkunjung Dengan Citra Destinasi Sebagai Variabel Mediasi (Survei pada Wisatawan Jawa Timur Park 1 Kota Batu). J Adm Bisnis S1 Univ Brawijaya, 40(1),186-193.

Ismail, T., \& Rohman, F. (2019). The Role Of Attraction, Accessibility, Amenities, And Ancillary On Visitor Satisfaction And Visitor Attitudinal Loyalty Of Gili Ketapang Beach. J Manajemen Teori dan Terapan:149-165.

[KEMENPAR] Kementrian Pariwisata. (2019). Perkembangan bulanan wisatawan nusantara di Indonesia. Diakses pada [5Mei 2019].Tersedia pada http://www.kemenpar.go.id/.

Ni, G. A. D. P. A., Wirawa, I. G. P. , \& Linawati. (2014). The Image of Bali Tourism in Social Networking Media Ni. E-Journal Tour, 1(2), 128-138. doi:https://doi.org/10.24922/eot.v1i2.19425. https://ojs.unud.ac.id/index.php/eot/article/view/19425.

Saputra, E. S., \& Sarma, M. (2020). Analisis Pengaruh PeranMarketing Public Relationsterhadap Peningkatan Citra Lido Lakes Resort and Conference Sukabumi. Jurnal Manajemen dan Organisasi, 10(1), 36-47. doi:10.29244/jmo.v10i1.28859. https://journal.ipb.ac.id/index.php/jmo/article/view/28859.

Tjiptono, F. (2011). Strategi Pemasaran. Yogyakarta: Andi.

Wanda, I. B. K., \& E. P. (2018). Kepuasan Pengunjung ( Survei pada Pengunjung Situs Trowulan ). J Bisnis, 55(3),

83-91. http://administrasibisnis.studentjournal.ub.ac.id/index.php/jab/article/view/2307. 